education in Vienna where he attended the Josephinum under Hering and Lange. He qualified in 1864, and twelve years later was appointed professor of anatomy at Prague where he superintended the construction of an anatomical institute, and after his transfer to a corresponding chair in Vienna collaborated with C. Lange in creating a similar institute there. In 1877 he published a text-book on histology, of which the third edition appeared in 1888 , and in 1896-1900, in conjunction with Alois Dalla Rosa, brought out an anatomical atlas which went through fifteen editions, of which the third was translated into English by M. Eden Paul in 1919. His other anatomical works included contributions to the study of fatty tissue, the structure of the mesentery, the anatomy of the human thorax and the growth of bone. After his retirement he devoted himself to anthropology, his most important work on this subject being on the form of the occiput in the population of southern Germany. He died on November 13, 1920.

\section{Science and the Future of Man}

THE social contacts and obligations of science, which was a subject of frequent reference in the proceedings of the recent meeting of the American Association for the Advancement of Science at Columbus, Ohio, notably in the addresses by Dr. Wesley C. Mitchell, retiring president, and Dr. Julian S. Huxley (see Nature, February 10, p. 207, and March 2, p. 330), furnished an important thread in the argument when Dr. Kirtley F. Mather discussed the prospects of human survival in his Sigma $\mathrm{Xi}$ lecture on "The Future of Man as an Inhabitant of the Earth". On geological, palæontological and biological grounds he is prepared to allow man a future of probably at least some thousands of years. Even if this present age is an interglacial and not a post-glacial, man's specific adaptability to extremes of climatic environment, he maintained, would enable him to survive. There is, however, he argued, one circumstance which militates against man's prolonged survival. This is the fact that in his conquest of the material world, which is the fundamental characteristic of his recent progress in civilization, man is using up his capital, such as oil, at a far higher rate than he is using his income, that is, the products of natural increase; and a further and even more alarming feature is that that capital expenditure is increasing progressively as the enjoyment of its amenities extends to the less sophisticated peoples. Hence, Dr. Mather concludes, exhaustion of capital in possibly seventy years or less may seriously curtail man's future.

Notwithstanding this depressing outlook, Dr. Mather does not despair of the future entirely in this respect, for he points out that science in its practical application has come to the rescue, and it may be anticipated will do so even more, by the provision of substitutes which will take the place of the capital material now being expended. He gives as an instance the substitutes for the oils, notwithstanding cost, and the same applies to other non-renewable resources. Another consequence of the activities of science in providing substitutes for these capital resources, of even greater topical interest at the moment, is that by liquidating international rivalries in pursuit of the policy of 'grabbing' the sources of supply, science will liquidate the basis of international jealousies and "may make it truly practical to beat our 'swords into ploughshares, our spears into pruning-hooks'." Finally, in regard to the organization of society, Dr. Mather pointed out that in the present rivalry of ideologies, the man of science as citizen must in the future give more thought to the social consequences of his work. He must determine the uses to which the tools he devises may be put, and ensure the wise use of knowledge and constructive application of energy. In a democracy this can be achieved only when the majority of its citizens have the scientific attitude towards social problems and act in accordance with that attitude of mind-a Herculean but not impossible task for education.

\section{Norwegian Fauna}

Hostilities in Norway threaten some of the most interesting of European mammals, especially so the large deer, the numbers of which have already been reduced by excessive hunting, and which may be exterminated there as a result of food shortage, just as the European bison was exterminated from many of its European haunts in the War of 1914-18. In Norway, the European moose or elk (locally known as the elg or stordyr) has its strongholds in Sorlandet in the south-east, Ostlandet in the east and Trondelagen in the middle of the country. In some parts of the country it had received total protection by law and in other parts sportsmen were allowed to shoot only a limited number of bull moose during a short season at the end of September. In recent years more than a thousand moose have been shot in Norway in a year, compared with four or five hundred wild reindeer and two or three hundred red deer. There are also roe deer, lynxes and other mammals and a 20,000 acres national park existed for their protection at Sognligaard.

In recent years, Dr. $\mathrm{Hj}$. Broch and the Nature Protection Society of Norway have done much to protect and increase such interesting birds as the osprey, kite, honey-buzzard and hen-harrier, whose nesting numbers were threatened. The 1932 Norwegian game laws protected all owls except the eagle and snowy owls, swans, pheasants, partridges, eider duck, woodcock, and gave a nesting season protection to most useful species. The smew nests in the north of the country, goosanders and mergasers on the waters, puffins, black guillemots and eiders about the rocky coasts, and there are also eagles, brent geese, herons, ravens, crossbills, bullfinches, shrikes, wrynecks, terns and divers. The Scandinavian peninsula has been shown to be the nesting haunt of many of the redwings, fieldfares, common gulls, starlings, wood-pigeons and woodcock visiting Britain in winter. The black woodpecker which nests here has been recorded in Britain on more than twenty occasions, including the last winter, and many ornithologists contend that these may be wild visitors. 